\title{
30 LAT PÓŹNIEJ: PROBLEM RZAZDÓW PRAWA W EXPOSÉ MINISTRÓW SPRAW ZAGRANICZNYCH POLSKI Z PERSPEKTYWY 1990 I 2019 R.
}

\author{
30 YEARS LATER: THE ISSUE OF THE RULE OF LAW \\ IN THE EXPOSÉS OF MINISTERS OF FOREIGN AFFAIRS OF \\ POLAND FROM THE PERSPECTIVE OF 1990 AND 2019
}

Przemysław Brzuszczak

\begin{abstract}
- ABSTRAKT
$-$

Artykuł stanowi próbę porównania obecności problematyki rządów prawa w dorocznych exposé ministrów spraw zagranicznych RP z perspektywy 1990 i 2019 r. Impulsem do wzmiankowanej analizy wystąpień Krzysztofa Skubiszewskiego i Jacka Czaputowicza były: 30. rocznica powołania rządu Tadeusza Mazowieckiego i - co się z tym wiąże - zapowiedź ustanowienia standardów prawnych charakterystycznych dla zachodnich demokracji liberalnych oraz, siłą rzeczy, bieżący spór wokół praworządności w Polsce. Okoliczności te sprawiły, że zagadnienie rządów prawa zajęło istotne miejsce $\mathrm{w}$ przemówieniach obu szefów dyplomacji.

W artykule dokonano analizy wystąpień obu ministrów spraw zagranicznych. Kwestia praworządności pojawia się w nich w następujących kontekstach: krajowym (transformacja wymiaru sprawiedliwości i towarzyszący jej dyskurs) oraz międzynarodowym, obejmującym relacje Polski
\end{abstract}

The article constitutes an attempt at comparing the existence of the issue of the rule of law in annual exposés of the Ministers of Foreign Affairs of the Republic of Poland from the perspective of 1990 and 2019. The impulse for the said analysis of speeches given by Krzysztof Skubiszewski and Jacek Czaputowicz consists in: the $30^{\text {th }}$ anniversary of establishment of the Tadeusz Mazowiecki's government and the related announcement of establishing legal standards characteristic for Western liberal democracies and, inevitably, the current dispute concerning the legality in Poland. These circumstances resulted in the issue of the rule of law taking a significant place in the speeches of the aforementioned heads of diplomacy.

The article presents analysis of speeches given by both Ministers of Foreign Affairs. The issue of legality appears therein in three main contexts: national (transformation of the judiciary and accompanying discourse) and international,

* Szkoła Główna Handlowa w Warszawie, Kolegium Nauk o Przedsiębiorstwie; Uniwersytet Warszawski, Wydział Nauk Politycznych i Studiów Międzynarodowych. 
z innymi państwami (ze szczególnym uwzględnieniem państw sąsiedzkich) i organizacjami międzynarodowymi (Rada Europy - przez pryzmat przede wszystkim Europejskiego Trybunału Praw Człowieka, Unia Europejska, ONZ).

O ile minister Skubiszewski w pewnym sensie wyznaczył w swym exposé „punkt wyjścia” polskiej polityki zagranicznej (w tym zobowiązanie do implementacji międzynarodowych standardów ochrony praw człowieka), tak Jacek Czaputowicz „punkt dojścia”, bowiem najistotniejsze cele wolnej Polski w sferze stosunków zewnętrznych zostały na przestrzeni 30 lat zrealizowane. Zmiana polityczna, jaką przyniosły wybory parlamentarne w 2015 r., sprawiła, że problem rządów prawa w Polsce stał się - także w polityce zagranicznej - na powrót aktualny.

Słowa kluczowe: rządy prawa; exposé ministra spraw zagranicznych RP; Jacek Czaputowicz; Krzysztof Skubiszewski; prawa człowieka; Unia Europejska covering relations of Poland with other states (including, in particular, neighbouring states) and international organisations (Council of Europe predominantly in the framework of the European Court of Human Rights, the European Union, the United Nations).

Whereas Minister Skubiszewski in a sense indicates in his exposé "the starting point" of the Polish foreign affairs policy (including the obligation to implement international standards of the protection of human rights), Jacek Czaputowicz indicates "the destination", since the most important aims of free Poland in the scope of external relations have been achieved in the course of 30 years. The political change brought by the parliamentary elections in 2015 resulted in the issue of the rule of law in Poland becoming current again, also in the foreign affairs policy.

Keywords: rule of law; exposé of the Minister of Foreign Affairs of Poland; Jacek Czaputowicz; Krzysztof Skubiszewski; human rights; European Union

\section{WPROWADZENIE}

Przypadająca na 12 września 2019 r. 30. rocznica powołania rządu Tadeusza Mazowieckiego była dobrą okazją do przypomnienia postępu, jakiego dokonała Polska w poszczególnych obszarach życia publicznego. W tym kontekście najczęściej wymieniano reformy gospodarcze (ze szczególnym uwzględnieniem przekształceń własnościowych), przemiany ustrojowe, samorząd terytorialny, politykę społeczną, zmiany w wymiarze sprawiedliwości i politykę zagraniczną. W sferze dyplomacji transformacja była może nawet bardziej znacząca aniżeli w obrębie gospodarki. O ile bowiem ostatnie rządy PRL-u poczyniły pewne kroki w kierunku systemu wolnorynkowego (choćby współcześnie mitologizowane poczynania ówczesnego ministra przemysłu Mieczysława Wilczka, umożliwiające rozwój przedsiębiorczości, czy uwolnienie cen przez gabinet Mieczysława Rakowskiego), to gdy idzie o stosunki zewnętrzne Polski, zasadniczą reorientację w tym zakresie przeprowadził dopiero rząd „naszego premiera”. Zmiany te, w największym skrócie, objęły uniezależnienie się od Związku Radzieckiego (wobec którego Polska Ludowa pozostawała państwem satelickim) przy równoczesnym 
obraniu kursu euroatlantyckiego (sprowadzającego się do hasła „powrotu do Europy”, relatywnie bliskiej współpracy ze Stanami Zjednoczonymi oraz akcesji Rzeczypospolitej do kolejnych organizacji międzynarodowych).

Ministrowie spraw zagranicznych rokrocznie przedstawiają założenia i plany w obrębie polityki zagranicznej Polski oraz sprawozdają się z dokonań dyplomatycznych $\mathrm{z}$ ostatnich 12 miesięcy w „Informacji ministra spraw zagranicznych o polityce zagranicznej Rzeczypospolitej Polskiej”. Ów dokument szefowie dyplomacji przedstawiają na forum Sejmu RP podczas wystąpienia nazywanego zwyczajowo „dorocznym exposê". To najważniejsze krajowe wystąpienie programowe przedstawiciela rządu na temat roli Polski we współczesnych stosunkach międzynarodowych. Tradycję tę zapoczątkował w 1919 r. ówczesny premier i minister spraw zagranicznych Ignacy Jan Paderewski. Od 1985 r. szefowie dyplomacji prezentują swoje exposé w cyklu corocznym (Podemski, 2017, s. 186).

\section{PROBLEM RZĄDÓW PRAWA A REORIENTACJA POLITYKI ZAGRANICZNEJ POLSKI PO 1989 R.}

Co łączy z punktu widzenia dotychczasowych rozważań wzmiankowane w tytule artykułu lata 1990 i 2019? W 1990 r. informacji na temat polityki zagranicznej Polski na forum Sejmu RP udzielał pierwszy po 1945 r. niekomunistyczny szef dyplomacji. Krzysztof Skubiszewski - bo o nim mowa - miał zaprezentować priorytety w obszarze polityki zagranicznej państwa w okresie tranzycji. Reorientacja kierunków dyplomatycznych jawiła się w owym czasie nieomal jako oczywista. Niemniej, trzeba przypomnieć, działo się to jeszcze przed upadkiem Związku Radzieckiego. Stąd też konieczne okazało się w przemówieniu Skubiszewskiego zachowanie pewnego balansu między kursem euroatlantyckim a tym wschodnim.

Polska polityka zagraniczna w pierwszych miesiącach po odzyskaniu suwerenności była zorientowana - dokonując tu daleko idącej symplifikacji - na dwie węzłowe kwestie. Pierwsza z nich to ułożenie relacji ze Związkiem Radzieckim w nowej rzeczywistości politycznej. Oznaką słabości upadającego imperium były nerwowe reakcje Moskwy na tendencje narodowowyzwoleńcze w republikach radzieckich. Wydarzenia te uwydatniały nieprzewidywalność sytuacji wewnątrz Związku Sowieckiego, czego ilustrację stanowił nieudany pucz pod wodzą wiceprezydenta ZSRR Giennadija Janajewa w sierpniu 1991 r. (blisko rok po pierwszym wystąpieniu programowym Skubiszewskiego). Polska w tym newral- 
gicznym okresie kierowała się „polityką dwutorowości”. Z jednej strony wspierała pragnienia niepodległościowe ludności w republikach ZSRR, z drugiej - starała się okazywać to w sposób możliwie subtelny, relatywnie łagodny, by nadto nie zadrażniać stosunków z Kremlem. Było to nader istotne w kontekście wsparcia dążeń Warszawy do udziału w konferencji „2 + 4” przez przywódcę ZSRR oraz negocjacji w sprawie wyprowadzenia wojsk radzieckich z Polski (Brzuszczak, 2019, s. 158-159).

Drugą z najważniejszych płaszczyzn działań polskiej dyplomacji był odcinek niemiecki. Pośród wielu kwestii związanych z relacjami Polski i Niemiec znalazł się m.in. problem zjednoczenia RFN i NRD, sprawa granicy na Odrze i Nysie Łużyckiej czy prawa mniejszości. Nie należy zapominać tu również o sferze symbolicznej, niemniej o dużej doniosłości - pojednanie polsko-niemieckie i „polsko-niemiecka wspólnota interesów” wymagały długoletnich wysiłków ze strony tak liderów politycznych, jak i szeregu urzędników, dyplomatów, działaczy organizacji pozarządowych czy naukowców. Tak przepastne obszary tematyczne jak stosunki Polski z ZSRR i Niemcami, siłą rzeczy, miały pierwszeństwo przed pozostałymi polami aktywności polskiej polityki zagranicznej (Brzuszczak, 2019, s. 159).

Jacek Czaputowicz wygłaszał swoje ministerialne exposé już w zmienionych uwarunkowaniach geopolitycznych. Mamy bowiem do czynienia z państwem, które w znacznym stopniu przepracowało „traumę wielkiej zmiany” (Sztompka, 2000). Polska stała się członkiem licznych organizacji międzynarodowych, dołączając tym samym do grona państw zachodnich - stanowiących przez wiele lat punkt odniesienia w zakresie przemian, choćby w sferze gospodarczej, oświatowej, prawnej, last but not least - dyplomatycznej. Bodaj największymi wyzwaniami na przestrzeni tych lat była akcesja do Paktu Północnoatlantyckiego i Unii Europejskiej, a następnie próba sprawnego odnalezienia się w tych strukturach już jako ich pełnoprawny członek. Wystąpienie Czaputowicza było 30. tego rodzaju przemówieniem szefa dyplomacji III Rzeczypospolitej. Ciągłość ta ma w sobie silny pierwiastek symboliczny. Owa tradycja nie jest przecież autoryzowana przez jakiś akt prawny. Stanowi ona, tout court, zwyczaj parlamentarny. Między oboma wystąpieniami - Krzysztofa Skubiszewskiego w 1990 r. i Jacka Czaputowicza w 2019 r. - doszukać się można dość istotnego iunctim. Poświęcono w nich stosunkowo dużo miejsca zagadnieniu rządów prawa. Paradoks polega na tym (by nie napisać wprost - chichot historii), że o ile u progu wolnej Polski minister Skubiszewski deklarował odwrót od praktyk państwa autorytarnego i reformy w duchu demokratycznego państwa prawnego, 
tak jeden $\mathrm{z}$ jego następców koncentrował się na zapewnianiu społeczności międzynarodowej o przestrzeganiu zasad praworządności. Znamienne, że Jacek Czaputowicz w okresie pełnienia przez Skubiszewskiego funkcji ministra spraw zagranicznych (1989-1993) był zatrudniony w gmachu przy al. Szucha na stanowiskach dyrektorskich (tak więc nie sposób uznać jego rolę w kształtowaniu polityki zagranicznej za mało istotną).

Zagadnienie rządów prawa zajmuje w mowach obu szefów dyplomacji znaczące miejsce. $Z$ biegiem lat $\mathrm{w}$ dorocznych wystąpieniach ministrów spraw zagranicznych zauważalne jest rozbudowywanie ich o kolejne wątki. Jest w tym jakaś osobliwość - wszak u progu wolnej Polski więcej spraw jawiło się jako nierozwiązanych, nieoczywistych. I tak - granica Polski z Niemcami na Odrze i Nysie Łużyckiej, stosunki z dotychczasowym wschodnim hegemonem, dążenia narodowowyzwoleńcze w obrębie ZSRR czy też polskie aspiracje do członkostwa w organizacjach międzynarodowych, do której od dawna przynależały już zachodnie demokracje liberalne. O ile wypowiedź Krzysztofa Skubiszewskiego z 26 kwietnia 1990 r. ma charakter dość ogólny, wskazuje priorytety, celnie punktuje najważniejsze „tu i teraz” kwestie, tak exposé Jacka Czaputowicza cechuje szczegółowość, niemal chęć poruszenia wszelkich możliwych wątków (tak by żaden z członków korpusu dyplomatycznego nie poczuł się urażony). Można by ocenić je wręcz jako „przegadane”. Przyjrzyjmy się językowi, jakim posługują się wspomniani politycy, jakich środków retorycznych używają, jak postrzegają problem rządów prawa.

\section{PROBLEM RZĄDÓW PRAWA W EXPOSÉ KRZYSZTOFA SKUBISZEWSKIEGO (1990)}

Krzysztof Skubiszewski jako minister spraw zagranicznych wygłosił po raz pierwszy swoje exposé w Sejmie 26 kwietnia 1990 r. Jest ono z perspektywy problematyki rządów prawa mniejsze objętościowo od omawianego w dalszej części tekstu exposé Jacka Czaputowicza. Trudno jedynie na podstawie analizy obu wystąpień pod kątem występowania w nich wyrażeń związanych $\mathrm{z}$ tą tematyką wyciągać daleko idące wnioski. Przywołajmy jednak dla porządku rzeczoną statystykę. Pośród kategorii wpisujących się w szeroko pojęty dyskurs rządów prawa w wystąpieniach Skubiszewskiego i Czaputowicza pojawiają się odpowiednio następujące określenia: „prawa człowieka” (jeden raz u tego pierwszego i siedmiokrotnie u tego drugiego), „praworządność” (1-2), „prawo 
międzynarodowe” (3-2), „prawo" rozumiane jednak obiegowo, np. „mamy prawo do..." (3-3), „prawa obywateli", rozumiane też jako prawa mniejszości narodowych i etnicznych (vide: Dąbrowski, 2009, s. 24-36) - zwłaszcza Polonii (jeden raz w mowie Skubiszewskiego i 7 razy w przemówieniu Czaputowicza), „podstawowe swobody”, „uprawnienia” $i$ „niesprawiedliwość” (po jednym razie u Skubiszewskiego), „prawa mniejszości religijnych” (raz u Czaputowicza), wreszcie różnie odmieniany przymiotnik „prawny” (3 razy u Skubiszewskiego i 10 razy u Czaputowicza). Wstępne rozpoznania co do powyższych rezultatów znajdą się w dalszej części artykułu, niemniej godzi się napomknąć, że w exposé ministra spraw zagranicznych w rządzie Mateusza Morawieckiego większa liczba niektórych przytoczonych wyrazów niekoniecznie ma charakter intencjonalny. Tytułem przykładu - „prawa człowieka” pojawiają się w kontekście organów międzynarodowych (np. Europejski Trybunał Praw Człowieka, Rada Praw Człowieka ONZ), częstotliwość sformułowania „prawa obywateli” to funkcja bieżących wydarzeń (brexit, działalność norweskiego urzędu ds. dzieci), a określenie „prawny” to przejaw jurydyzacji języka, inflacji różnego rodzaju instytucji prawnych (np. „opinie prawne”, „ramy prawne”, „podstawy prawne").

Szef dyplomacji w rządzie Tadeusza Mazowieckiego wymienił w swoim pierwszym sejmowym exposé poszanowanie praw człowieka jako jeden z 9 priorytetów polskiej dyplomacji: „Będziemy umacniać w stosunkach międzynarodowych praworządność, a więc będziemy umacniać funkcję prawa międzynarodowego; szczególna troska towarzyszyć będzie ochronie praw człowieka i podstawowych swobód" (Skubiszewski, 1997b, s. 44). W wypowiedzi tej dostrzec można „rękę" profesora prawa międzynarodowego - Skubiszewski postrzegał je jako fundament współczesnych stosunków międzynarodowych nie tylko ze względów zawodowych, lecz także jako polityk. Inna sprawa, że „trzecia fala demokratyzacji” (Huntington, 1991) i towarzyszące jej liczne zmiany granic wzmogły zapotrzebowanie na prawników-internacjonalistów i zainteresowanie prawem międzynarodowym. Ot, lesprit du temps (Morin, 1983).

Przywołany fragment przemówienia ministra Skubiszewskiego w warunkach zachodniej demokracji liberalnej zostałby uznany za mający jedynie walor ornamentacyjny. Zupełnie innej symboliki nabierał jednak w świetle przemian zachodzących tak w Polsce, jak i na świecie na przełomie dwóch ostatnich dekad XX w. Nawiązanie do tej wypowiedzi będzie się pojawiać, mniej bądź bardziej świadomie, w kolejnych informacjach ministrów spraw zagranicznych o polityce zagranicznej Rzeczypospolitej. 
W wystąpieniu w Sejmie 26 kwietnia 1990 r. szef MSZ w odniesieniu do Narodów Zjednoczonych akcentował szczególnie problem ochrony środowiska naturalnego. Tak oto ujmował ten jeden $z$ kluczowych celów prowadzonej przezeń polityki zagranicznej: „Współpraca $\mathrm{z}$ organizacjami międzynarodowymi, specjalnie z Organizacją Narodów Zjednoczonych, zwłaszcza w rozwiązywaniu problemów globalnych. Tutaj na pierwszym miejscu stoi ochrona środowiska. Interesują nas, rzecz jasna, nie tylko posunięcia na skalę światową. Mamy na uwadze ochronę środowiska naturalnego zarówno Polski, jak regionu, do którego Polska należy, w ścisłym związku z ogólnoeuropejską strategią ekologiczną" (Skubiszewski, 1997b, s. 43-44). Symptomatyczne, że fragment ten zajmuje relatywnie dużo miejsca w dość krótkim - w odniesieniu do exposé ministra Czaputowicza - przemówieniu i to w warunkach mniejszej świadomości społeczności międzynarodowej co do ważkości problematyki „ekologicznej”. Blisko 30 lat później (gdy zmiany klimatyczne to przedmiot zainteresowania nie tylko zdeklarowanych ekologów) w analogicznej, dłuższej, mowie szefa dyplomacji określenie „ochrona środowiska” występuję ledwie raz - w kontekście pomocy rozwojowej dla państw Globalnego Południa. To wszystko w okresie, gdy polskie władze przedstawiają swoje państwo jako czempiona przemian ekologicznych. Już osobną kwestią pozostaje związek tych enuncjacji z rzeczywistością - czy nie mają one w sobie czegoś z wishful thinking.

Znamienne w wystąpieniu Skubiszewskiego jest nieco inne niż współcześnie rozłożenie akcentów, gdy mowa o działalności Konferencji Bezpieczeństwa i Współpracy w Europie. O ile obecnie Organizacja Bezpieczeństwa i Współpracy w Europie ${ }^{1}$ konotuje w pierwszej kolejności kwestię praw ludzkich, tak w latach 1975-1995 było to zagadnienie bezpieczeństwa międzynarodowego. Początkowo przedstawiciele już wolnej Polski również nie postrzegali problematyki praw człowieka jako głównego celu jej aktywności na forum KBWE. Logika geopolityczna nakazywała widzieć w tej strukturze nade wszystko regionalnego poręczyciela bezpieczeństwa i respektowania suwerenności. Krzysztof Skubiszewski w dorocznym exposé wygłoszonym w Sejmie 26 kwietnia 1990 r. pośród priorytetów polskiej polityki zagranicznej wymienił w pierwszej kolejności właśnie te zagadnienia: „Będziemy współtworzyć system bezpieczeństwa europejskiego i tym samym współdziałać na rzecz jedności naszego kontynentu.

1 Zmiana nazwy to rzecz jasna wynik przekształcenia dotychczasowej Konferencji w organizację międzynarodową z początkiem $1995 \mathrm{r}$. 
Istotnym narzędziem i płaszczyzną działania jest Konferencja Bezpieczeństwa i Współpracy w Europie (KBWE). Uważamy, że rola siły wojskowej w polityce europejskiej winna ulegać stałemu ograniczaniu. Będziemy rozbudowywać nasze powiązania $z$ organizacjami i ugrupowaniami europejskimi, zwłaszcza ze Wspólnotami Europejskimi i z Radą Europy" (Skubiszewski, 1997b, s. 43-44). Szef MSZ silnie podkreślał w różnych wypowiedziach potrzebę umiędzynarodowienia problematyki bezpieczeństwa. Proces ten określił jako „denacjonalizację” bezpieczeństwa (Skubiszewski, 1997c, s. 106). Tego rodzaju figury retoryczne $\mathrm{w}$ tamtym czasie stanowiły niewątpliwie signum temporis.

\section{PROBLEM RZĄDÓW PRAWA W EXPOSÉ JACKA CZAPUTOWICZA (2019)}

\section{Kwestia praw obywateli Polski poza jej granicami}

W exposé Jacka Czaputowicza z 14 marca 2019 r. jako pierwszy wątek ze sfery szeroko rozumianych rządów prawa pojawił się ten dotyczący ochrony obywateli Polski mieszkających w Wielkiej Brytanii w kontekście jej wyjścia ze struktur Unii Europejskiej (vide: Wodak, 2011, s. 22-29). Niewątpliwie problem brexitu jest tym, wokół którego istotnie koncentruje się uwaga analityków polityki zagranicznej. Przywołajmy rzeczony fragment wystąpienia szefa dyplomacji: „Na wypadek brexitu bez porozumienia rząd brytyjski przedstawił plan ochrony obywateli Unii Europejskiej, w tym Polaków, natomiast rząd polski przyjął pakiet rozwiązań legislacyjnych chroniących prawa mieszkających w naszym kraju Brytyjczyków" (Czaputowicz, 2019). W świetle tych słów, paradoksalnie, wydarzenie o wymiarze bez mała globalnym, nie tylko europejskim, nabiera dość lokalnego kolorytu. Ów wyimek z exposé jest, zdaje się, zorientowany jednak na wywołanie efektu wewnętrznego. Rząd dbający o swych obywateli rozrzuconych po świecie - to przekaz płynący z tej wypowiedzi. Trudno w tym miejscu czynić zarzut, że takie deklaracje pojawiają się w najważniejszym krajowym wystąpieniu ministra spraw zagranicznych. Zasadne jest tu raczej pytanie, czy w przemówieniu tym właściwie rozłożono akcenty - odnosi się bowiem wrażenie, że rodzima optyka (rozumiana również jako obrona interesów obywateli Polski poza jej granicami) przyćmiewa perspektywę międzynarodową.

Za ilustrację powyższych spostrzeżeń niech posłuży również podobny problem, wymieniony przez ministra Czaputowicza już w końcowej części 
wystąpienia - sprawa Polonii w Norwegii, głośna ostatnimi czasy w związku $\mathrm{z}$ doniesieniami medialnymi o działalności tamtejszego urzędu ds. dzieci (Barnevernet). Idzie tu o odmienne standardy w podejściu do wychowania dzieci (w domyśle: te konserwatywne, podkreślające rodzinną hierarchię versus te liberalne, promujące partnerskie relacje między rodzicami a dziećmi). Szef dyplomacji wskazywał: „Uwagę opinii publicznej przykuły ostatnio działania naszej placówki w Norwegii na rzecz ochrony rodzicielskich praw obywateli polskich i praw samych dzieci. Polscy konsulowie podejmują kontakt $\mathrm{z}$ norweskimi służbami socjalnymi, weryfikują ich działania, a w razie potrzeby interweniują w celu ochrony życia rodzinnego naszych obywateli. Ochrona praw Polaków jest jednym z fundamentów działań naszej dyplomacji” (Czaputowicz, 2019). W wypowiedzi tej - w zderzeniu z innymi, o których za chwilę, wrogo traktującymi wszelką ingerencję organów międzynarodowych w „polskie sprawy” - uderza brak konsekwencji. W jednej części wystąpienia minister spraw zagranicznych podkreśla prawo Polaków zamieszkujących za granicą do ochrony swojej, rzec by można, „tożsamości wychowawczej”, aby w innej odrzucać próby narzucania Polsce standardów praworządności charakterystycznych dla demokracji liberalnych. Sprawa wydaje się jednak poważna - zrazu incydentalne przypadki skarg polskich obywateli na działalność Barnevernetu urosły do rangi bodaj najważniejszego problemu relacji dwustronnych. Materia ta przesłoniła nawet takie zagadnienia jak bezpieczeństwo energetyczne czy krajowy podział Funduszy Norweskich (ich operatorem miałyby w większym zakresie stać się agendy rządowe kosztem organizacji pozarządowych), które wyznaczały ostatnio stosunki na linii Warszawa - Oslo. Szef polskiej dyplomacji dostrzegł wzmiankowane trudności, wskazując wprost: „Dążymy także do poprawy bilateralnej współpracy z Norwegią w zakresie ochrony małoletnich. Na początku marca, kilka dni temu, odbyła się wizyta studyjna pracowników norweskich urzędów ds. ochrony dzieci, w czasie której omówiliśmy zagadnienia stanowiące największe wyzwania dla współpracy transgranicznej" (Czaputowicz, 2019).

Podobnie - jak w przypadku Polonii w Wielkiej Brytanii i Norwegii - ma się rzecz z fragmentem wystąpienia Jacka Czaputowicza dotyczącym stosunków polsko-niemieckich. Został on zdominowany przez kwestię praw społeczności polskiej za zachodnią granicą. Nie ma ona statusu mniejszości, jak to się dzieje w przypadku Niemców zamieszkujących w Polsce, co nastręcza pewnych trudności i staje się przedmiotem troski kolejnych rządów. Przywołajmy stosowne fragmenty mowy szefa MSZ: „[...] wyzwaniami w relacjach polsko-niemieckich pozostają zagadnienia związane z prawami Polonii i Polaków mieszkających 
w Niemczech. Pozytywnym sygnałem jest, że w tym roku dojdzie do spotkania Polsko-Niemieckiego Okrągłego Stołu, poświęconego m.in. sytuacji społeczności polskiej w Niemczech” (Czaputowicz, 2019) czy: „Podczas rozmów z rządem federalnym konsekwentnie podejmujemy kwestie poprawy warunków rozwijania i pogłębiania tożsamości kulturowej i językowej przez osoby polskiego pochodzenia w Niemczech. Mamy nadzieję, że planowane w czerwcu rozmowy Polsko-Niemieckiego Okrągłego Stołu z udziałem przedstawicieli rządów oraz społeczności polskiej w Niemczech i niemieckiej w Polsce pozwolą na osiągnięcie wymiernych efektów, szczególnie w zakresie nauczania języka polskiego jako języka ojczystego, realizacji remontu i działalności Domu Związku Polaków w Niemczech w Bochum oraz upamiętnienia w Niemczech polskich ofiar II wojny światowej, w tym przedwojennej mniejszości polskiej" (Czaputowicz, 2019). Nietrudno odnieść wrażenie, że wypowiedzi te są zorientowane na użytek wewnętrzny. Rząd prezentuje się tu jako obrońca polskości, wykazuje asertywność $\mathrm{w}$ relacjach $\mathrm{z}$ wpływowym sąsiadem, podejmuje zagadnienia wpadkowe nieistotne dla szerszej publiczności, ale mające pewne znaczenie symboliczne dla Polaków zamieszkujących w Niemczech. To dość zgrabne, zręczne retorycznie fragmenty exposé na tle całego wystąpienia.

W analogiczny sposób do wątku społeczności polskiej w Niemczech, jak się zdaje, skonstruowany jest ustęp poświęcony prawom Polaków na Litwie: „Ministerstwo Edukacji Narodowej prowadzi rozmowy z Litwą o poprawie warunków funkcjonowania polskiego systemu oświaty w tym kraju. Od maja 2018 r. odbieranych jest na Wileńszczyźnie pięć kanałów TVP, co przyczynia się do umocnienia polskości, ale także do uodpornienia się naszych rodaków na rosyjską dezinformację. Ważnym wydarzeniem będzie planowane uruchomienie TVP Wilno. Dzięki współpracy Ministerstwa Spraw Zagranicznych i Telewizji Polskiej oraz zaangażowaniu lokalnego polskiego środowiska dziennikarskiego możliwe będzie docieranie z przekazem na temat współczesnej Polski, jej kultury i historii bezpośrednio do naszych rodaków na Litwie" (Czaputowicz, 2019). Pewne zastanowienie może budzić fragment traktujący o roli TVP w kontekście polityki informacyjnej Kremla („uodpornienie się naszych rodaków na rosyjską dezinformację"). Tło tej wzmianki sprawia wrażenie oczywistego - wzmożona prokremlowska agitacja wynikająca z konfliktu rosyjsko-ukraińskiego. Wypada jednak przywołać jeszcze co najmniej jedną okoliczność. W okresie dążeń narodowowyzwoleńczych w obrębie Związku Radzieckiego na przełomie lat 80. i 90. ubiegłego wieku mniejszość polska w ówczesnej Socjalistycznej Republice Litewskiej nie poparła gremialnie działań na rzecz uniezależnienia się tej ostatniej od 
ZSRR. Część Polaków na Litwie widziała wówczas w Moskwie sprzymierzeńca w mitygowaniu antypolskich nastrojów.

Jacek Czaputowicz niejako podsumował powyższe trudności dotyczące polskich obywateli poza granicami państwa: „Będziemy dopominać się o prawa Polaków wszędzie tam, gdzie nie są one właściwie chronione, korzystając w razie potrzeby - także $\mathrm{z}$ forów wielostronnych" (Czaputowicz, 2019). Brzmi to nieco jak to, co w języku potocznym zwykliśmy nazywać „straszakiem”. W każdym razie takie wrażenie mogliby w jakimś stopniu odnieść zgromadzeni na balkonach sali plenarnej Sejmu dyplomaci innych państw.

\section{Aktywność Polski na rzecz bezpieczeństwa i praw człowieka na forach międzynarodowych}

Gdy idzie o problem rządów prawa w przemówieniu ministra Czaputowicza, trzeba też sygnalizacyjnie wspomnieć o kwestiach natury operacyjnej czy instytucjonalnej. Polityk ten uwypuklał, w jego mniemaniu, rosnącą na arenie międzynarodowej pozycję Warszawy, przywołując aktywność Polski w obrębie struktur Narodów Zjednoczonych: „Jako niestały członek Rady Bezpieczeństwa aktywnie podejmujemy starania na rzecz zapewnienia pokoju na świecie”, czy też: „W 2018 r. Polska angażowała się skutecznie we współpracę wielostronną, zwłaszcza na forum Rady Bezpieczeństwa ONZ oraz w ramach kampanii na rzecz wyboru do Rady Praw Człowieka. Realizacja priorytetu Polski w Radzie Bezpieczeństwa, jakim jest promocja prawa międzynarodowego, była realizowana w ramach debaty otwartej wysokiego szczebla [...]" (Czaputowicz, 2019).

Jeszcze innym głośnym wydarzeniem w ostatnich miesiącach była organizacja w Warszawie w lutym 2019 r. konferencji bliskowschodniej. Jacek Czaputowicz wskazywał: „Wyrazem naszego zaangażowania w [...] obszarze [zapewnienia pokoju na świecie - P.B.] była konferencja nt. możliwości zapewnienia bezpieczeństwa i stabilizacji na Bliskim Wschodzie" (Czaputowicz, 2019). Pośród zagadnień będących przedmiotem zainteresowania zarówno uczestników wydarzenia, jak i polskiej dyplomacji w ogóle wymienił kwestie humanitarne, problematykę dotyczącą uchodźców oraz prawa człowieka. Stanowisko polskiego rządu wobec kryzysu migracyjnego nie wymaga tu specjalnej rekapitulacji. Najogólniej mówiąc, wyraża ono niechęć do aktywnego zaangażowania na rzecz przełamania międzynarodowego impasu w tej sferze. Innymi słowy - brzmi to jak uspokajanie własnych sumień. Przykładem powyższego może być również 
następująca wypowiedź: „W 2018 r. i na początku 2019 r. organizowaliśmy lub współorganizowaliśmy szereg spotkań poświęconych sytuacji ludności cywilnej w konfliktach zbrojnych" (Czaputowicz, 2019). Organizacja tego rodzaju wydarzeń - mówiąc wprost - nic nie kosztuje w kategoriach moralnych i politycznych.

Już choćby ze względu na doświadczenie pokojowych przemian na przełomie lat 80. i 90. minionego stulecia Polska posiadała (posiada?) silny mandat do promocji poza granicami państwa problematyki praw człowieka i praworządności. Wypada przyznać, że specyfika polskiej transformacji stanowiła w pewnej mierze inspirację do reform politycznych w takich państwach jak Birma (Mjanma), Tunezja czy Ukraina. Potencjał ten jawi się jednak wciąż jako niewykorzystany (żeby nie ująć tego dosadniej - zmarnowany). Pamięć o „rewolucji Solidarności”2 (Friszke, 2014) to ciągle mocna karta. Godzi się zauważyć, że polska dyplomacja zachowuje dość selektywną postawę wspierania działaczy na rzecz praw człowieka. O ile jakieś formy pomocy dostrzec można w przypadku aktywistów wywodzących się z państw, z którymi Polska ma napięte relacje (vide: Rosja), i tych niebędących czołowymi aktorami stosunków międzynarodowych, to jeśli chodzi o takie państwa jak: Chiny, Turcja czy Azerbejdżan, łatwo spostrzec, że prymat mają tu relacje gospodarcze w myśl powiedzenia business as usual. W tym względzie Jacek Czaputowicz w swoim exposé przekonywał: „Polska wspiera obrońców praw człowieka oraz kontakty między osobami działającymi na rzecz przemian demokratycznych na świecie. W trakcie siódmego Warszawskiego Dialogu na rzecz Demokracji gościliśmy kilkudziesięciu przedstawicieli społeczeństwa obywatelskiego z całego świata. Nagrodę ministra spraw zagranicznych Pro Dignitate Humana wręczono w ubiegłym roku ukraińskiemu reżyserowi Ołehowi Sencowowi w uznaniu jego zasług w dziedzinie obrony praw człowieka” (Czaputowicz, 2019).

Sygnalizowana wyżej wybiórczość, przynajmniej w sensie retorycznym, w podejściu do praw ludzkich przejawia się również w innym miejscu wystąpienia szefa MSZ: „W marcu tego roku, w tym miesiącu Polska została przyjęta do Międzynarodowej Grupy na rzecz Wolności Religii i Wyznania, której celem jest zacieśnianie współpracy i koordynacja działań w sprawie promocji wolności religii. Traktujemy to jako uznanie dla naszych aktywnych działań na rzecz ochrony praw osób należących do mniejszości religijnych, w tym chrześcijan" (Czaputowicz, 2019). Wypowiedź ta wpisuje się w szerszy trend - po 2015 r. polskie władze deklarują w pierwszej kolejności wsparcie dla społeczności identyfiku-

2 Posługuję się tu określeniem upowszechnionym przez Andrzeja Friszkego. 
jących się z „narodowymi wartościami”. Egzemplifikacją tego jest akcentowanie przyjęcia na polski rynek pracy dużej liczby migrantów zarobkowych z Ukrainy czy konieczności ochrony - w kontekście wojny domowej w Syrii - jezydów podzielających właśnie chrześcijańskie wartości (jakkolwiek jezydyzm to nurt synkretyczny). W przeświadczeniu rządzących obie te - wymienione jedynie tytułem przykładu - grupy nie zagrażają wspólnocie narodowej, jej względnej jednolitości (Rittel, 2016, s. 212-236).

\section{Polska versus Europejski Trybunał Praw Człowieka}

Interesująco na płaszczyźnie dyskursywnej przedstawia się ten oto wywód ministra Czaputowicza: „Zauważalną tendencją jest też spadek liczby skarg skierowanych przeciwko Polsce do Europejskiego Trybunału Praw Człowieka. W 2018 r. złożono 1941 nowych skarg, o 120 mniej niż rok wcześniej. Dla porównania, jeszcze w 2010 r. do Trybunału w Strasburgu skierowano 5768 nowych skarg. W konsekwencji tych tendencji liczba nowych skarg przeciwko Polsce w stosunku do liczby mieszkańców utrzymywała się w ubiegłym roku poniżej średniej europejskiej. Jednocześnie dbamy o wykonywanie orzeczeń Europejskiego Trybunału Praw Człowieka. Na koniec ubiegłego roku osiągnięty został rekordowo niski poziom 100 orzeczeń zawisłych w procedurze wykonywania. Dla porównania: w 2015 r. niewykonanych pozostawało 313 orzeczeń, a w 2011 r. takich orzeczeń było 924" (Czaputowicz, 2019).

Komunikat, jaki płynie z powyższego fragmentu przemówienia, jest pozornie przejrzysty - polski rząd odnotował dwa sukcesy: primo, spadła liczba skarg składanych przez polskich obywateli do Trybunału Strasburskiego; secundo, zmniejszeniu uległa również liczba niewykonanych orzeczeń tegoż sądu. Bardziej wnikliwy czytelnik czy słuchacz wystąpienia szefa polskiej dyplomacji spostrzeże inną prawidłowość: zwiększyła się liczba wykonywanych orzeczeń Europejskiego Trybunału Praw Człowieka, ergo spadła liczba skarg kierowanych doń. W tym miejscu należy wskazać, że znaczna część z dotychczasowych skarg polskich obywateli dotyczyła kwestii natury systemowej, np. warunki przebywania w więzieniach, nadużywanie instytucji aresztu. Inna sprawa - wpływ na wspomniane statystyki mają także choćby takie czynniki jak rosnąca tendencja do zawierania ugód ze skarżącymi, piętrzące się co rusz formalizmy postępowania przed ETPC („ucieczka w formalizm”), wydłużający się czas oczekiwania na zapadnięcie wyroku czy przyczyny nieformalne, wolicjonalne (np. nastawienie 
urzędników Trybunału w Strasburgu do poszczególnych spraw)33 (Bunda, 2018). Przytoczony fragment exposé ministra Czaputowicza uwydatnia jedną z bolączek polskiej debaty publicznej - bezrefleksyjne przywoływanie różnorakich statystyk (co ma zrobić wrażenie na czytelnikach czy słuchaczach, że mają do czynienia z merytokracją) bez opatrzenia ich komentarzem, skąd się wzięły owe liczby, jaki jest ich kontekst.

\section{Polska versus Komisja Europejska}

Last but not least - może najbardziej wymierną kwestią w dziedzinie rządów prawa, szeroko dyskutowaną ostatnimi czasy, była propozycja powiązania wypłat środków unijnych ze stanem praworządności w państwach członkowskich (Ryniejska-Kiełdanowicz, 2007a, s. 11-35; Ryniejska-Kiełdanowicz, 2007b). Ujawnia się tu praktyczny aspekt rule of law, odczuwalny dla obywateli i piastunów władzy publicznej. Nie ma bowiem li tylko charakteru werbalnych napomnień czy ostrzeżeń ze strony instytucji międzynarodowych (głównie europejskich), w których zawiera się krytykę poczynań obozu sprawującego władzę. Gdyby propozycja przedstawicieli Komisji Europejskiej urzeczywistniła się, byłaby realnym zagrożeniem dla stanu finansów publicznych (zwłaszcza $\mathrm{w}$ dobie gospodarczej prosperity, ambitnych zapowiedzi inwestycyjnych). Minister Czaputowicz wskazywał: „Nie do przyjęcia jest propozycja Komisji uzależnienia wypłaty środków $\mathrm{z}$ budżetu Wspólnot od arbitralnie ocenianego stanu praworządności w państwach, którym środki te są przyznawane. Wypłata tych środków jest traktatowym zobowiązaniem. W propozycji Komisji uderza brak precyzji kryteriów oceny praworządności, silnie obniżony próg blokowania decyzji, a przede wszystkim - brak podstaw prawnych do takich działań. Państwa członkowskie nie nadały ani Komisji Europejskiej, ani też ciału stricte politycznemu jakim jest Rada prawa sądzenia, a jedynie kompetencje do kierowania spraw do Trybunału Sprawiedliwości UE” (Czaputowicz, 2019).

Przytoczone słowa szefa polskiej dyplomacji kontrastują z retoryką stosowaną przez zwolenników głębokich zmian w wymiarze sprawiedliwości, które od 2015 r. przeprowadza obóz rządzący. Osoby te, nie dysponując mocnymi argumentami natury prawnej (lex), próbują przenieść spór na niwę polityczną

\footnotetext{
3 Na uwarunkowania te wskazuje w swoim artykule w „Polityce” Martyna Bunda (Bunda, 2014).
} 
czy też, zazwyczaj w sposób dość wątpliwy, odwoływać się do wyższych racji (ius), jak choćby: Bóg, wola suwerena, sprawiedliwość ponad prawem (jak gdyby obie te wartości miały ze sobą kolidować). Ma to kapitalne znaczenie dla odbiorców owych polemik. W przypadku konfliktów prawnych koniec końców zapada jakieś prawomocne orzeczenie, pełnomocnicy stron przedstawiają argumenty znajdujące zakotwiczenie w dotychczasowym orzecznictwie sądowym czy literaturze specjalistycznej. Spór polityczny rządzi się swoimi prawami. Widz czy słuchacz reaguje najczęściej w taki oto sposób: „,jedni i drudzy kłamią”, „prawda leży gdzieś pośrodku”, „ten ma trochę racji i tamten ma trochę racji”. Innymi słowy - tego rodzaju chwyt retoryczny „rozmywa” sedno problemu.

W kontekście tych spostrzeżeń trzeba zauważyć, że Jacek Czaputowicz użył $\mathrm{w}$ analizowanym fragmencie wystąpienia argumentacji o charakterze prawnym: zarzut arbitralności rozstrzygnięć, odwołanie się do litery traktatów europejskich, brak precyzyjnych kryteriów oceny stanu praworządności w państwach członkowskich. Polski minister zdaje się mówić - pacta sunt servanda! Abstrahując już od zasadności tych argumentów, wypada jednak oddać mu, że starał się posługiwać językiem typowym dla argumentacji prawniczej (na gruncie akademickim Jacek Czaputowicz jest, nawiązując tu do obecnie obowiązującej systematyki dziedzin i dyscyplin naukowych, przedstawicielem nauk o polityce i administracji), a nie jedynie tej charakterystycznej dla polityka.

\section{ZAKOŃCZENIE}

Analizowane wyżej przemówienia dwóch ministrów spraw zagranicznych są zupełnie niezłym miernikiem tego, jaką drogę pokonała Polska przez ostatnie 30 lat. Do 2015 r. (i w pewnym stopniu w latach 2006-2007) polska dyplomacja podążała dość linearną ścieżką, charakterystyczną dla zachodnich demokracji liberalnych, którą wyznaczały kolejne akcesje do organizacji międzynarodowych, coraz śmielsze inicjatywy na forum światowym (na czele z włączeniem się w wojnę w Iraku w 2003 r.), unormowanie stosunków z sąsiadami - przede wszystkim Litwą, Niemcami i Ukrainą, w miarę pragmatyczne relacje z Federacją Rosyjską przeplatane poważnymi kryzysami (co jest widoczne zwłaszcza po 2010 r.). Słowem, jakkolwiek by to osobliwie nie zabrzmiało w turbulentnej rzeczywistości międzynarodowej, kierunki polityki zagranicznej były na swój sposób przewidywalne, kolejni szefowie dyplomacji zazwyczaj kontynuowali działania swych poprzedników. 
Wystąpienie szefa MSZ w rządzie Tadeusza Mazowieckiego jest zorientowane bardziej na partnerów zewnętrznych niż polską opinię publiczną. W przemówieniu Jacka Czaputowicza dominuje perspektywa polonocentryczna, skierowana „do wewnątrz”, nastawiona na wpisanie się w szerszą opowieść polityczną obozu rządzącego (Krzyżanowski, 2008, s. 267-303). Przykładem tego jest choćby poświęcenie tak wiele miejsca w exposé ochronie interesów obywateli Polski poza jej granicami czy też ukazywanie Rzeczypospolitej przez pryzmat wkładu w politykę światową. $\mathrm{W}$ informacji ministra spraw zagranicznych na temat polskiej polityki zagranicznej z 2019 r. dostrzec można potrzebę uwypuklenia wydarzeń z historii Polski, które określilibyśmy jako „dawanie moralnego świadectwa".

W exposé Krzysztofa Skubiszewskiego Polska jawi się jako państwo należące ideowo „od zawsze” do świata zachodniego, choć z perspektywy 1990 r. wciąż rozpostarte geopolitycznie między Okcydentem a Wschodem. Z kolei w przemówieniu Jacka Czaputowicza przynależność do struktur euroatlantyckich jest brana jako pewnik, coś, od czego nie ma odwrotu. W jakimś sensie minister Skubiszewski wyznacza w swym wystąpieniu „punkt wyjścia” polskiej polityki zagranicznej, zaś Jacek Czaputowicz „punkt dojścia”, bowiem najistotniejsze cele wolnej Polski w sferze stosunków zewnętrznych zostały na przestrzeni 30 lat zrealizowane. Celnie ujął to w swoim artykule Krzysztof Podemski: „Po przełomie roku 1989 Polska jest ukazywana jako państwo pogranicza, położone między Wschodem a Zachodem. Miejsce na Wschodzie wynika z geografii i niedawnej przynależności do Układu Warszawskiego i RWPG. Kulturowo i historycznie należymy do Zachodu, do obozu państw demokratycznych i respektujących prawa człowieka. Jednak gospodarczo i politycznie stanowimy jeszcze jego peryferia" (Podemski, 2017, s. 219). Najnowsza historia polityczna Rzeczypospolitej przyniosła jednak zaskakującą woltę. Anno Domini 2019 już mało kto kwestionował gospodarczą i polityczną przynależność Polski do struktur euroatlantyckich. Wątpliwości budzi natomiast obecne podejście do kwestii rządów prawa. W exposé ministra spraw zagranicznych z 1990 r. można dostrzec obietnicę systematycznego postępu w tej dziedzinie, rozbudowy mechanizmów typowych dla demokratycznego państwa prawa. W 2019 r. szef dyplomacji - w imieniu swojego rządu - czuł się zobligowany do zapewniania opinii międzynarodowej o poszanowaniu przez państwo standardów praworządności. Niezależnie od wymiaru zarówno deskryptywnego, jak i normatywnego problemu rządów prawa w Polsce już sam fakt wygłoszenia takiego oświadczenia jest symptomatyczny. 
BiBLIOGRAFIA:

Biel, Ł., Broś, K., Jopek-Bosiacka, A. (2017). Polityka zagraniczna i integracja europejska w uchwałach Sejmu w latach 1950-2014. Swoi - Inni - Obcy. W: M. Czyżewski, A. Horolets, K. Podemski, D. Rancew-Sikora (red.). Polskie sprawy 1945-2015. Warsztaty analizy dyskursu (s. 225-259). Warszawa: Wydawnictwo Akademickie SEDNO.

Bieńczyk-Missala, A. (2005). Prawa człowieka w polskiej polityce zagranicznej po 1989 roku. Warszawa: Wydawnictwa Uniwersytetu Warszawskiego.

Bieńczyk-Missala, A., Kuźniar, R. (red.) (2007). Prawa człowieka w polskiej polityce zagranicznej. Warszawa: Polski Instytut Spraw Międzynarodowych.

Brzuszczak, P. (2019). Prawa człowieka w polityce zagranicznej rządu Tadeusza Mazowieckiego. Toruń: Wydawnictwo Adam Marszałek.

Bunda, M. (2018). Blokada polskich skarg do Strasburga. Polityka z 18 września 2018 r.

Ceranka, P. (red.) (2013). Exposé ministrów spraw zagranicznych 1990-2013. Warszawa: Ministerstwo Spraw Zagranicznych. Biuro Archiwum i Zarządzania Informacją.

Czaputowicz, J. (2019). Informacja Ministra Spraw Zagranicznych o zadaniach polskiej polityki zagranicznej w 2019 r. Pobrane z: https://www.gov.pl.

Czyżewski, M., Dunin, K., Piotrowski, A. (red.) (2010). Cudze problemy. O ważności tego, co nieważne. Analiza dyskursu publicznego w Polsce. Warszawa: Wydawnictwo Akademickie i Profesjonalne.

Czyżewski, M., Otrocki, M., Piekot, T., Stachowiak, J. (red.) (2017). Analiza dyskursu publicznego. Przeglad metod i perspektyw badawczych. Warszawa: Wydawnictwo Akademickie SEDNO.

Dąbrowski, M. (2009). Komparatystyka dyskursu. Dyskurs Komparatystyki. Warszawa: Dom Wydawniczy Elipsa.

Duszak, A., Fairclough, N. (red.) (2008). Krytyczna analiza dyskursu. Interdyscyplinarne podejście do komunikacji społecznej. Kraków: UNIVERSITAS.

Duszak, A., Kowalski, G. (red.) (2013). Systemowo-funkcjonalna analiza dyskursu. Kraków: UNIVERSITAS.

Friszke, A. (2014). Rewolucja Solidarności 1980-1981, Kraków: Wydawnictwo Znak.

Horolets, A. (red.) (2008). Analiza dyskursu w socjologii i dla socjologii. Toruń: Wydawnictwo Adam Marszałek.

Huntington, S.P. (1991). The Third Wave. Democratization in the Late Twentieth Century. Norman: University of Oklahoma Press.

Kissinger, H. (1994). Diplomacy. New York: Simon \& Schuster.

Kukułka, J., Zięba, R. (red.) (1992). Polityka zagraniczna państwa. Warszawa: Wydawnictwa Uniwersytetu Warszawskiego.

Kunter, A. (2012). Analiza dyskursu, tłum. M. Höffner. W: D. Jemielniak (red.). Badania jakościowe. Metody i narzędzia, t. 2 (s. 189-201). Warszawa: Wydawnictwo Naukowe PWN.

Kuźniar, R. (2008). Droga do wolności. Polityka zagraniczna III Rzeczypospolitej, Warszawa: Wydawnictwo Naukowe Scholar. 
Mazowiecki, T. (1989a). Będzie to rząd koalicji na rzecz reformy państwa i naprawy gospodarki. Przemówienie Tadeusza Mazowieckiego wygłoszone w Sejmie 24 sierpnia 1989 r., Trybuna Ludu z 25 sierpnia 1989 r.

Mazowiecki, T. (1989b). Polacy rozpoczynają nową kartę swej historii. Oświadczenie premiera Tadeusza Mazowieckiego wygłoszone w Sejmie 12 września 1989 r. Rzeczpospolita z 13 września 1989 r.

Melissen, J. (red.) (2005). The New Public Diplomacy. Soft Power in International Relations. London: Palgrave Macmillan.

Morgenthau, H.J. (1979). Human Rights \& Foreign Policy. New York: Council on Religion \& International Affairs.

Morin, E. (1983). L'Esprit du temps, Paris: Grasset.

Nye, J.S. (2004). Soft Power. The Means to Success in World Politics. New York: Public Affairs.

Nye, J.S. (2011). The Future of Power. New York: Public Affairs.

Ociepka, B. (2009). Komunikowanie polityczne w środowisku międzynarodowym: podmioty dyplomacji publicznej. W: M. Kolczyński, M. Mazur, S. Michalczyk (red.). Mediatyzacja kampanii politycznych (s. 88-101). Katowice: Wydawnictwo Uniwersytetu Śląskiego.

Ociepka, B. (2013). Miękka siła i dyplomacja publiczna Polski. Warszawa: Wydawnictwo Naukowe Scholar.

Piekot, T., Poprawa, M. (red.) (2012). Analiza dyskursu. Centrum - peryferie. Wrocław: Wydawnictwo Uniwersytetu Wrocławskiego.

Podemski, K. (2017). Polska kosmografia polityczna. Analiza sejmowych exposé ministrów spraw zagranicznych w latach 1945-2015. W: K. Podemski, M. Czyżewski, A. Horolets, D. Rancew-Sikora (red.). Polskie sprawy 1945-2015. Warsztaty analizy dyskursu (s. 183-223). Warszawa: Wydawnictwo Akademickie SEDNO.

Przyłęski, P. (2012). Populizm w polskiej polityce. Analiza dyskursu polityki. Warszawa: Wydawnictwo Sejmowe.

Rittel, S.J. (2016). Analizy dyskursu tekstowego. Kraków: Collegium Columbinum.

Ryniejska-Kiełdanowicz, M. (2007a). Kształtowanie wizerunku Polski w Unii Europejskiej. W: B. Ociepka (red.). Kształtowanie wizerunku (s. 11-35). Wrocław: Wydawnictwo Uniwersytetu Wrocławskiego.

Ryniejska-Kiełdanowicz, M. (2007b). Public relations Polski w okresie kandydowania do Unii Europejskiej. Wrocław: Wydawnictwo Uniwersytetu Wrocławskiego.

Skubiszewski, K. (1997a). Polityka zagraniczna i odzyskanie niepodległości. Przemówienia, oświadczenia, wywiady 1989-1993. Warszawa: Wydawnictwo INTERPRESS.

Skubiszewski, K. (1997b). Polityka zagraniczna odrodzonego państwa. Doroczne exposé wygłoszone w Sejmie w dniu 26 kwietnia 1990 r. W: idem, Polityka zagraniczna i odzyskanie niepodległości. Przemówienia, oświadczenia, wywiady 1989-1993. Warszawa: Wydawnictwo INTERPRESS.

Skubiszewski, K. (1997c). Polska a bezpieczeństwo europejskie. Przemówienie wygłoszone podczas Zgromadzenia Północnoatlantyckiego. Londyn, 29 listopada $1990 \mathrm{r}$. 
W: K. Skubiszewski, Polityka zagraniczna i odzyskanie niepodległości. Przemówienia, oświadczenia, wywiady 1989-1993. Warszawa: Wydawnictwo INTERPRESS.

Sztompka, P. (2000). Trauma wielkiej zmiany. Społeczne koszty transformacji, Warszawa: Instytut Studiów Politycznych Polskiej Akademii Nauk.

Wodak, R. (2011). Wstęp: badania nad dyskursem - ważne pojęcia i terminy. W: R. Wodak, M. Krzyżanowski (red. ). Jakościowa analiza dyskursu w naukach społecznych, tłum. D. Przepiórkowska (s. 11-48). Warszawa: Oficyna Wydawnicza Łośgraf. Wodak, R., Krzyżanowski, M. (red.) (2011). Jakościowa analiza dyskursu w naukach społecznych, tłum. D. Przepiórkowska. Warszawa: Oficyna Wydawnicza Łośgraf.

Zięba, R. (2010). Główne kierunki polityki zagranicznej Polski po zimnej wojnie. Warszawa: Wydawnictwa Akademickie i Profesjonalne. 